\title{
ASPECTS CONCERNING THE IMPACT OF CLIMATE ARIDIZATION ON FOREST ECOSYSTEMS (CASE STUDY)
}

\author{
Nedealcov Maria ${ }^{1}$, Donica Ala ${ }^{2}$, Brașoveanu Valeriu ${ }^{2}$,Grigoraș \\ Nicolae $^{2}$, Deomidova Cristina ${ }^{2}$
}

Key words: climate change, aridity, forest ecosystems, oak, bioindicators

\begin{abstract}
Assessment activity and surveillance of the forests health, held at the global, regional and local level, has continuously developed, culminating in the current period with interdisciplinary and extensive scientific researches, that evaluate the effects of the main factors on forest ecosystems state, in particular, air pollution and climate change.Scientific researches have shown that among trees ecophysiological processes, forest life processes and meteorological parameters there are direct dependences, particularly in the case of trees supply with water during the growing period (May-July), with major influences for critical months (July and August), which have a decisive impact on growth, vitality and production of organic matter in forests.Dry years, from the beginning of the third millennium can lead to a decrease of mesophilic forests area (beech, sessile oak and penduculate oak), which will tend to retreat towards the center of the area (central Europe) in favor of thermophilic forests with pubescent oak.It was determined that a most significant negative impact of climate aridization will feel the forest ecosystems from Southern and central regions of country (conditioned by the mean air temperature (July-August), monthly rainfall (May-August), evapotranspiration and geographic latitude), and less - the Northern part of the country (Forestry Aridity Index calculated for 3 experimental stations revealed variations of this index between 7.8 - 8.3 - in the Central part of country, and 8.4 8.6 - for Southern part of country).At the same time the impact of climate change will determine the spatial and temporal dynamics of pests and pathogenic species. The phenomenon of climate aridization was expressed also through the impact of the Microsphaera alphitoides disease, intensity of "mildew" attack being based on the climatic conditions of the study region. Obtained data, for confirmation, were correlated with indications of bioindicators, present in the study region.
\end{abstract}

\footnotetext{
${ }^{1}$ Laboratory of Climatology and Environmental Risks, Institute of Ecology and Geography, ASM, Republic of Moldova

${ }^{2}$ Research group "Forest Eco biochemistry”, Institute of Ecology and Geography, ASM, Republic of Moldova
} 


\section{Introduction}

The forest ecosystems represent a biotic, natural and strategic potential, which through their structural and functional diversity fulfill a number of functions - maintain ecological equilibrium, protect the land and water resources, improves the natural landscape and the microclimate of natural and anthropogenic ecosystems, etc. The degradation of forest resources influences the state of other natural resources and can be a limiting factor for the development of the local and national economy as a whole. The forests of the Republic of Moldova are predominant by deciduous species $(97.8 \%)$, of which the oaks are dominant - 39.6\%, followed by acacia - 36.1\%, ash - $4.6 \%$, hornbeam - $2.6 \%$, poplars - $1.6 \%$, other deciduous species $-13.4 \%$ and softwoods $-2.1 \%$ (Galupa D., et al., 2011). The most valuable tree stands of the forest fund are the oaks.According to (Raport privind....,2011) of their total area $27 \%$ come from the seed and $73 \%$ from the shoots, which also influences their productivity, thus $43 \%$ being of superior productivity and $57 \%$ of inferior productivity. The process of acacia expanding areas, in the last period, economically convenient, has reduced the importance of indigenous species, some of them being at their area' limits (oak, beech, maple, etc.).

In the context of climate change, felt also on the Republic of Moldova territory (Nedealcov M., 2012), forest ecosystems suffer significant changes due to the temperature of the air, the increase of $\mathrm{CO} 2$, the changes in the precipitation regime, frequency and severity of the extreme meteorological phenomena, etc. The major consequences, felt by forest ecosystems, consist in the appeared changes in phenology processes, vitality, growth of trees, and the amount of forest biomass (IPCC Report, 2014).

Scientific researches in domain have shown that there is a direct dependence between the ecophysiological processes of the trees, the vital processes of the forest and the meteorological parameters, especially in the case of tree supply with water in the tree growing period (May to July), with major influences in critical months (July and August), which have a decisive impact on the growth and vitality of trees, and production of organic matter in forests. Thus, the evapotranspiration rate is higher in these periods, and forest ecosystems are most sensitive to extreme weather conditions.It is remind that the central and eastern mesophilic forests from the North and the center of our country are at the South-Eastern limit of its natural area, and the dry years from the beginning of the third millennium may lead to a diminution of mesophilous forests (Fagus sylvatica, Quercus petraea, Quercus robur), which will tend to retreat to the center of the area (central Europe), in favor of the thermophilous forests with Quercus pubescens from the South of the country (Ecosistemele: evaluarea vulnerabilităților, 2010). 
The actuality of such studies is also conditioned by the requirements of various national and international environmental acts (Environmental Strategy of the Republic of Moldova, for the years 2014-2023; Biological Diversity Strategy of the Republic of Moldova for the years 2015-2020; Strategy for the Sustainable Development of the Forest Sector of the Republic of Moldova; Strategu of the Republic of Moldova to Climate Change Adaptation by 2020; Convention on Biological Diversity, 1992; Convention on Climate Change, 1994; etc.).

\section{MATERIALS AND METHODS}

The studies were carried out during 2016, with the main objective of identifying the impact and natural and technological risks on forest ecosystems, for the development of solutions and models for sustainable management and protection of forests, within the framework of the Applicative Project " Integrated assessment of human impact on representative ecosystems for the purpose of conservation and extension of Natural State Protected Areas in the EU directives context" at the Institute of Ecology and Geography. The research included both:

- the field stage: spatial location of experimental areas - based on programs developed and adopted at European level (ICP Forests, 2010);study of the main dendrometric characteristics (Badea O., 2008); collection and storage of biological material accumulated as a result of field expedition - according to standard methods (Клейн P., et al., 1974, Ivan D., et al., 1975); appreciation of crown defoliation, leaf discoloration and mechanical damage (ICP Forests methodology, 2010); AND

- laboratory stage: description of physico-geographic parameters Territorial-Administrative Map of Republic of Moldova-RM (scale 1: 400000), 2008; Physical Map of RM (scale 1: 200000), 1998; Physico-Geographical Regional Map of RM, 2009; Geomorphological Regional Map of RM (1: 750000), 1978; The Tectonic Map of RM (1: 1000000), 1978; Atlas of RM (1978); Map of the experimental areas location, Level I and II, within the European Forest Monitoring Network from the Republic of Moldova;mapping of research stations based on geoinformational programs (eg.: ArcGis, Google Earth, etc.); collection of data necessary for research: meteorological parameters - temperature, precipitation, air humidity, wind direction, and emissions of pollutants into the air - according to the informative bulletins of the State Hydrometeorological Service; quota of the transboundary pollution with SO2 for the Republic of Moldova - according to EMEP reports, based on polygons / grids; description of the dendrometric characteristics of the research areas analysis and reading of the forest facilities (Institute for Forest Research and 
Development);assessment of the natural and anthropogenic risks to which oak stands are subject - climate change, by calculating the forest aridity index (Moore B., et al., 2008; Fuhrer E., et al., 2011; Nedealcov M., et al. , 2016); identification of biological impact and pests on oak stands, based on trees affected by parasitic fungi of Ord. Erysiphales, causing "mildew" - using the scale proposed by Bevan R. J., et al., (1976), with some additions - percentage expression of the disease spread on the leaf surface, collected at the base and at the top of the slope (Ditu I., et al., 1963; Begu A., 2002, 2010; Obuh P., et al., 2006); determination of systematic belonging of the collected lichen species and their bioindicator role (Окснер А., 1956, Голубкова Н., 1966, Окснер А., 1970, Гарибова Л., 1978, Begu А., 2010); air quality assessment for SO2 content, according to the Air Quality Assessment Grades for the territory of theRepublic of Moldova (Begu A., 2010).

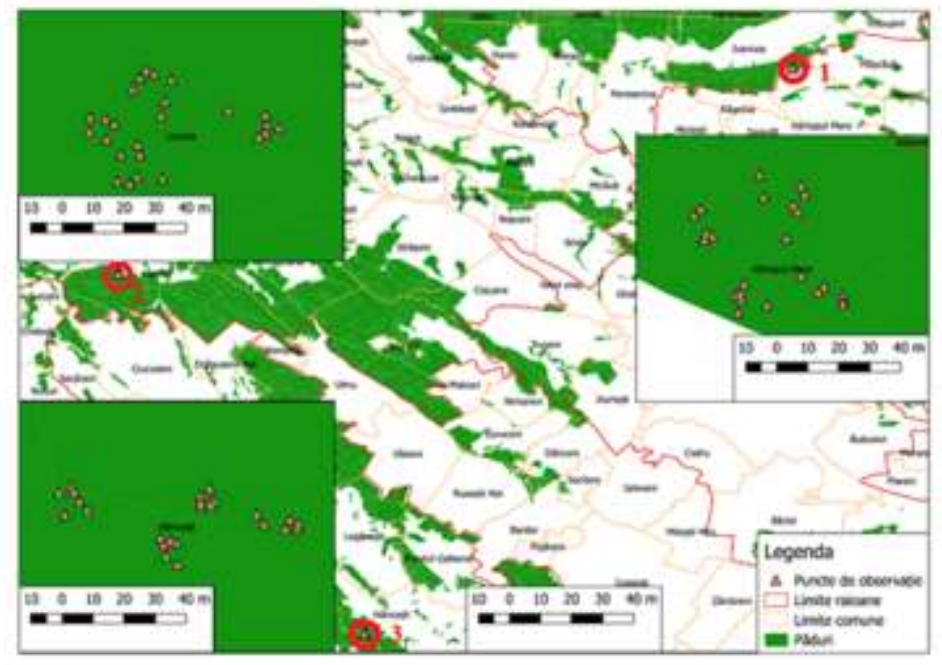

Fig.3. Location of investigated experimental areas

\section{RESULTS AND DISCUSSIONS}

The activity of assessing and supervising the health of forests, developed at the global, regional and local level, has continuously developed, culminating in the current period with extensive interdisciplinary scientific researches, assessing the effects of the main factors acting on the state of forest ecosystems, in particular, atmospheric pollution and climate change. An important element in the process of ensuring the preservation and development of forests is forest monitoring. This is a system of continuous surveillance of changes in the health 
of forest vegetation due to atmospheric and soil pollution, cuttings, deserts, recreational uses, etc.

Together with the inventory of the EA trees, besides the measurement and appreciation of the biometric characteristics of them, visually were estimated parameters for tree health status characterization - the crowns defoliation and the foliage discoloration, as well as the mechanical injuries of crown and tree trunk, produced by various abiotic and antropic factors.

Defoliation is one of the most important parameters and expresses the

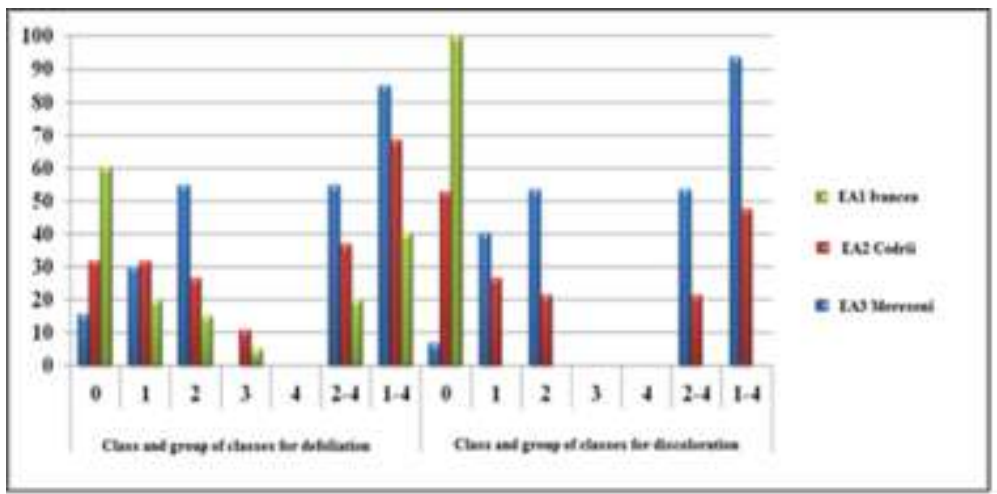

Fig.4. The degree of defoliation and discoloration, by class and group of classes, for the oak areas studied (2016), \%

loss of leaves from the crown of a tree, compared to another whose foliar appliance is complete (reference tree). Discoloration expresses the percentage of leaves (existing in the crown of the tree) whose color deviates trenchily from the normal color of the foliage of the species (yellow to rust). Mechanical (physical) injuries are determined by carefully examination of physical condition of each recorded tree, indicating the cause and severity of the injury (ICP-Forests Manual, 2010).

Thus, the share of healthy trees (Class 0) is highest in EA3 (60\%) followed by EA2 (32\%) and lowest in EA 1 (15\%). According to the magnitude of the injuries (grades 1-4), the same trend is observed, from moderate (EA3), to strong (EA2) and very strong (EA1).Thus, according to the parameters studied, defoliation and discoloration, we can deduce that the oaks from Orhei State Forestry Enterprise are the most affected, followed by those from Scientific Reserve "Codrii" and a better health condition is recorded for those of HânceștiSilva State Forestry Enterprise. The main factors responsible for the severity of the injuries are: climatic conditions (drought, high temperatures), impact of 
atmospheric pollutants and outbreaks of defoliant diseases and pests, as well as changes in relief forms, forest type, soil type, etc.

According to national data (Raport ICAS, 2015), at the level of forest monitoring network, Quercus petraea stands in our study areas (Orhei, Scientific Reserve "Codrii" and Hânceşti), compared to other areas of the Republic of Moldova, after defoliation and discoloration, fit, with the highest proportion, in class 0 - healthy trees and class 1 - poorly damaged trees.At the level of the National Forestry Fund - NFF, the highest degree of damage to Quercus petraea stands during the study period, was recorded in forestry units such as Cimislia, Şoldăneşti, Teleneşti and Plaiul Fagului, so we deduct a good health state of the durmast oak studied by us, compared to those of NFF.

In the case of Quercus robur species, we can not talk about the same tendency of health as Quercus petraea. According to national data,healthy trees (class 0) predominated, with the highest proportion, in forestry units such as: Tighina - 65\%, Manta-V - 74\%, Silva-Sud - 51\%, Bălți, Călărași, Iargara, Soroca, Chișinău, Edineț and Scientific Reserve "Codrii".Strong and very strong injuries (classes 1-4), caused by defoliators, have been detected for oak trees in Cimislia, Edinet, Glodeni, Orhei, Soldanesti and Domneasca Forest, with proportions of $79-100 \%$.Thus, at the level of NFF, the health status of Quercus robur, studied by us, can be considered moderate, with negative tendencies for pedunculate oak of Orhei State Forestry Enterprise.

According to national data (Raport ICAS, 2015), within the main species monitored at NFF level, the most injured (classes 1-4), after defoliation, are: oak (70\%) along with beech (83\%), elm (74\%) and maple (91\%).At individual species level, the highest intensity of injury (classes 2-4) is for beech - 35\% and for oak - $27 \%$.

Sustainable forest management is increasingly associated with assessments of environmental / habitat factors from different forest ecosystems. In this series of factors, a particular role is played by the climate, which tends to change.

Scientific researches in the field have shown that there is a direct dependence between the trees' eco-physiological processes, the vital processes of the forest and the meteorological parameters of the weather, especially in the case of the water supply of trees in the tree growing period (May to July) with major influences for the critical months (July and August), which have a decisive impact on the growth, vitality and production of organic matter in forests. The evapotranspiration rate is higher in these periods, and forest ecosystems are most sensitive to extreme weather conditions. The ratio of meteorological parameters to tree growth (proportional to organic matter production) can be characterized 
by the so-called Forestry Aridity Index (FAI), calculated for temperate forests (Fuhrer E. et al., 2011), by the formula:

$$
\mathrm{FAI}=100 *\left(\left(\mathrm{~T}_{\mathrm{VII}}+\mathrm{T}_{\mathrm{VIII}}\right) / 2\right) /\left(\mathrm{P}_{\mathrm{V}}+\mathrm{P}_{\mathrm{VI}}+2 *\left(\mathrm{P}_{\mathrm{VII}}+\mathrm{P}_{\mathrm{VIII}}\right)\right),
$$

where: $\mathrm{T}_{\mathrm{VII}-\mathrm{VIII}}-$ mean air temperature for July and August $\left({ }^{\circ} \mathrm{C}\right)$, $\mathrm{P}_{\mathrm{V}-\mathrm{VIII}}-$ sum of precipitation $(\mathrm{mm})$ fallen between May and August.

Through this index, we can describe the average weather conditions for different climatic categories and apply it in the practice of forestry.

The higher FAI's values indicate, for the critical period of the forest species, more dry and more arid conditions of development, and the lower FAI's values - wetter and warmer condition in growth period.

It was found that geographic latitude and absolute altitude are the main physical and geographic factors that influence the distribution of this index in our country.

For the territory of the Republic of Moldova this index is 5.70 for the Northern region, 8.35 for the central region and 10.75 for the South region of the country, so that the forest ecosystems in the south and the center of the country are most affected by the phenomenon of climate aridization.Such studies are necessary in predicting the possible impact of arid climate conditions on forest ecosystems on the country territory, which would facilitate the selection of tree species, provenance and genotypes, tolerant to existing climatic conditions (Nedealcov M. et al. 2016).

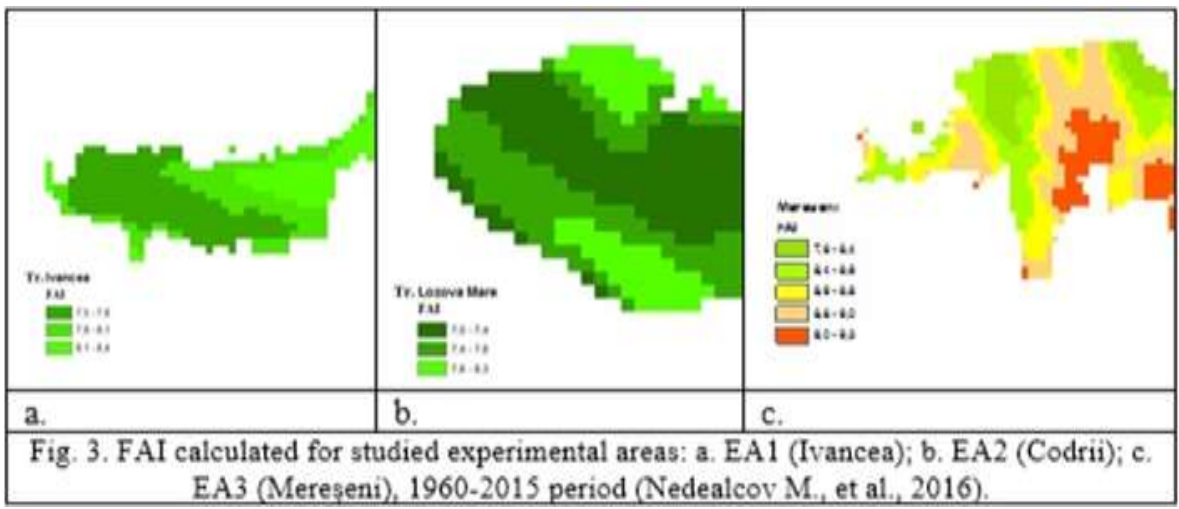

Calculating this index for each forest body in which EAs are located, FAI has been found to vary in value across the forest ecosystems in which the 
EAs were located, as explained by the adjacent parameters influencing the climate (forms of relief, inclination and exhibition of slopes, etc.).

Thus for EA1 (Ivancea) and for EA2 (Codrii) this index varies between 7.8-8.3, and for EA3 (Mereşeni) - 8.4-8.6 (Fig.3).

Analyzing the data on the health status of oak stands in the $3 \mathrm{EA}$, we observe some differences in the degree of injury, that increased as follows $($ EA3 $<$ EA2 $<$ EA1), Fig. 2.

The current state of forests health is influenced by various natural factors and forest management, which increases the degree of instability of forest ecosystems.Of these, the pathological factors are identified as the main cause of the damage to the tree health, the evolution of which is correlated with the climatic conditions (Raportul privind starea sectorului forestier, 2011).

According to the studies conducted by the Institute for Forest Research and Development (ICAS), defoliator pests are the most significant share of all pathological factors, such as: Limantria dispar, Tortrix viridana, Erannis defoliaria, Operophtera brumata, Stereonychus fraxini, etc.

Another biological factor responsible for forest disease and degradation of forest ecosystems in Moldova is the frequent diseases such as: Microsphaera alphitoides, Marssonina juglandis, Rhytisma acerinum, Fusarium, Alternaria, Pythium, Phellinus igniarius, etc.

The powdery mildews disease agent is native to North America.From here, it was introduced to Europe with the import of saplings and acorns, being reported in Portugal since 1877, whereupon it spread throughout the Iberique peninsula, France (1907), Italy, Germany, reaching the North Caucasus (1909).In 1908 it is also certified in Romania, in the Bratia forest (Ploiesti region), after 1910 to be certified in the entire area of the oaks in the respective country (Dițu I., et al., 1963).

Climate change already has direct and indirect effects on the temporal and spatial dynamics of pests and pathogens.The direct impact influences the frequency and intensity of outbreaks as well as spatial patterns, size and geographical area.The indirect impact is related to the influence of climate change on the nutritional quality of plants and their resistance, as well as the interactions of the community / population of species with their natural enemies.

Research on the oak dieback phenomenon draws even more attention to the impact of the oak mildew in the complex of harmful factors, which are manifested in the forest ecosystems of oaks.In this context, we mention the fact that climate change usually intensifies the attack of various diseases, or when oaks are physically "weakened" due to climate change, they will be less resistant to pathogens. 
Species of oak (especially Quercus robur) during a vegetation season can be infected successive with mildew. Because of this, there is a danger that secondary infections will occur for a long time (Diț I., et al., 1963). Studies in our country indicate that the intensity of the "mildew" attack is dependent on the climatic conditions, the disease being favored by temperatures between $25-30^{\circ} \mathrm{C}$ and the relative air humidity of 70\% (Obuh P., et al., 2006; Begu A., 2002).

The general climatic data of the researched sectors indicate an annual mean air temperature of $9.5^{\circ} \mathrm{C}$ (EA Ivancea), $10^{\circ} \mathrm{C}$ (EA Mereşeni) and $9^{\circ} \mathrm{C}$ in EA Codrii and values of annual mean precipitation, which varies between 600$650 \mathrm{~mm}$ (EA Mereşeni and Ivancea), and 650-700 $\mathrm{mm}$ - in EA Codrii (Nedealcov M., et al., 2013).

From the meteorological point of view, the spring of 2016 in the Republic of Moldova was warm and precipitated (the mean air temperature during the spring season (March-May) constituted in the territory +10.9 $+12.2^{\circ} \mathrm{C}$, which is $1.8-2.7^{\circ} \mathrm{C}$ higher than normal, being reported, on average, once in 10 years, and the amount of precipitation falling during spring on 55\% of the country's territory, was $108-138 \mathrm{~mm}$ or $80-120 \%$ of the norm), the State Hydrometeorological Service. Thus, in spring, the relatively warm rains and mean daily temperature allowed the ascospores release.In these conditions, are formed ascending air currents, which trace the ascospores from the surface of the soil, causing the infection of the leaves, first of the base ones (Fig.4).

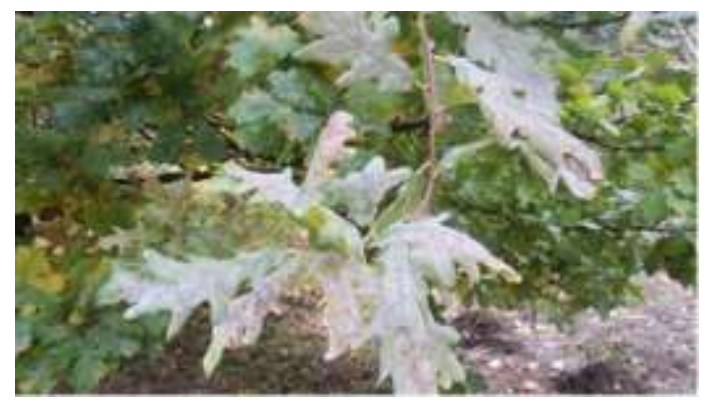

Fig.4. Oak leaves from EA2 (Codrii), attacked by oak powdery mildew (Microsphaera alphitoides)

The summer of 2016 and the first decades of September were quite dry and warm, or dry weather favors the detachment and spreading of conidia.

Applying the scale proposed by Bevan R.J., et al., (1976), with some additions (Dițu I., et al., 1963; Begu A., 2002, 2010; Obuh P., et al., 2006), it was concluded that in 2016 the climatic conditions caused the development of oak mildew, especially in EA3 Mereşeni, according to degree 5 of disease spreading 
where leaf surface damaged by this disease is more than 50\%; in EA2 Codrii according to degree 4 (about $40-50 \%$ of the leaf area was affected by the disease); whereas in EA1 Ivancea the development of mildew corresponded to degree 3, which caused a spread of the disease on about $20 \%$ of the leaf.

These data are confirmed by the specific diversity of epiphytic lichens in the region.Thus, the correlation of the data on the degree of spread of oak mildew with the Lichen Scale of Toxitoleration to $\mathrm{SO}_{2}$, (Begu A., 2010) indicated that inEA1- predominate lichen species sensitive to air pollution, degree of toxicotolerance II; in EA2 - species with moderate resistance, and degree of toxicotolerance III; and in EA3 - species with higher resistance, degree of toxicotolerance IV.

Data from the literature suggests that parasitic micromycetes, especially the representatives of Ord. Erysiphales, are recognized as indirect bioindicators of air pollution with $\mathrm{SO}_{2}$ (Obuh P., et al., 2006; Begu A., 2002). Thus, the spread of diseases (mildew, necrosis) on the surface of trees leaves is also directly dependent on the degree of air pollution with $\mathrm{SO}_{2}, \mathrm{H}_{2} \mathrm{~S}$, which during rains forms $\mathrm{H}_{2} \mathrm{SO} 4$ which destroys the parasitic fungus.As a preventive measure, it is proposed to avoid the increased spread of the mycelium (and consequently the formation of ascocarps, ascospores) by combating the micromycete in $\underline{\text { June }}$ (Begu A., 2002).

\section{Conclusions}

1. Central-European mesophilic forests from the North and the center of our country, located on the South-Eastern limit of its natural area, through the influence of various abiotic and biotic factors, diminish its spreading, so that the investigated experimental areas with representative and edifying species of oaks, come to reflect the current state of these valuable species as well as future trends in the manifestation of risks to their health.

2. The assessment of health state of the experimental researched areas, according to the defoliation, decoloration, physical injuries, indicates that in 2016 the oaks from Orhei State Forestry Enterprise are the most affected, followed by those from Scientific Reserve "Codrii", better state of health beeing recorded for the oaks in Hâncești-Silva State Forestry Enterprise, conditioned by abiotic and biotic factors (weather conditions, impact of atmospheric pollutants, influence of relief forms, forest type, soil type, outbreaks of defoliant diseases and pests etc.).

3. For the first time was calculated the Forestry Aridity Index for the territory of the Republic of Moldova (Nedealcov M., 2016), which represents 5.70 for the Northern region, 8.35 for the Central Region and 10.75, highlighting 
the fact that a more significant negative impact of climate aridization will be felt by the forest ecosystems in the South and the center of the country (conditioned by the air mean temperature (July - August), monthly rainfall (May-August), evapotranspiration and geographical latitude) .

4. The phenomenon of climate aridisation is also reflected by the impact of Microsphaera alphitoides on oaks from experimental areas, which indicated greater damage to oak trees in Mereşeni area (the 5th degree of spread of the disease - more than $50 \%$ of the leaf surface is affected by mildew), followed by trees in Codrii area (grade 4 - about 40-50\%), and Ivancea area (grade 3 - about $20 \%$ ), also confirmed by the correlations between the degree of spread of parasitic fungi of ord. Erysiphales on the leaves, and the annual mean of $\mathrm{SO}_{2}$ concentration in the air, as well as the specific diversity of epiphyte lichen in the investigated experimental areas.

\section{References}

Assessment of Epiphytic Lichen Diversity. Part XVII.2. Manual on methods and criteria for harmonized sampling, assessment, monitoring and analysis of the effects of air pollution on forests. United Nations Economic Commission for Europe. Convention on Long-range Transboundary Air Pollution. International Cooperative Programme on Assessment and Monitoring of Air Pollution Effects on Forests (ICP Forests). Version 5/2012. 14p

Atlas. Resursele climatice ale Republicii Moldova. Colectiv de aut.: Nedealcov M., Răileanu V., Chirică L., s..a. Acad. de Ştiinţe a Moldovei, Ministerul Mediului al Rep. Moldova, Inst. de Ecologie şi Geogr., Ch.: Î.E.P. Ştiinţa (în colaborare cu editura Strih SRL), 2013, $76 \mathrm{p}$

Badea O.: Manual privind metodologia de supraveghere pe termen lung a stării ecosistemelor forestiere aflate sub acțiunea poluării atmosferice și modificărilor climatice. Bucuresti, Tehnica Silvică, 2008. 98 p

Begu A: Aspecte privind infectarea speciilor de Quercus robur L. şi Acer tataricum L. cu ciupercile parazite din ord. Erysiphales, în: Mediul ambiant. 2(2), Ch., 2002, p. 11-14.

Begu A: Studiul ecobioindicației în Republica Moldova și implementarea ei în monitoringul calității mediului, Autoreferatul tezei de doctor habilitat în biologie. Ch., 2010, 45p.

Bergmann W: Colour Atlas Nutritional Desorders of Plants. Gustav Fischer Verlag Jena, Stuttgart, New York, 1992, p. 96-101

Bevan R.J., Greenhalgh G.N: Rhytisma acerinumas a biological indicator of pollution. Environ Pollut., 1976, 10, p. 271- 285

Boaghie D: Monitoring ecologic și forestier. Chișinău, 2004. 186 p 
Bolea V., Chira D., Popa M., Mantale C., Pepelea D., Gancz V., Surdu A., Iacoban C: Arborii bioindicatori şi bioacumulatori de sinteză în ecosistemul forestier. Analele ICAS 49: 67-77, București, 2006

Bonneau M : Le diagnostic foliaire. Revue Forestiere Francaise. Nancy, 1988, p. 19-28

Brașoveanu $\mathrm{V}$ : Riscurile poluării aeriene asupra speciilor edificatoare și ecobioindicatoare din cadrul rețelei de monitoring forestier. Autoreferatul tezei de doctor în științe biologice. Ch., 2014, 31p

Dițu I., Petrescu M., Dragomir N: Făinarea stajarului - criterii de avertizare și măsuri de combatere. Rev. Padurilor, nr. 1/1963, p. 209-231

Dițu I., Popescu T., Dragomir N: Cîteva rezultate privind combaterea făinării stejarului pe bază de avertizare. Rev. Padurilor, nr. 1/1962, p. 46-48

Donica A: Evaluarea stării ecologice din principalele zone de recreație ale mun. Chișinău în baza ecobioindicației. Autoreferat al tezei de doctor în biologie. Ch., Tipogr. Elena-V.I. SRL, 2007, 22p.

Ecosistemele: evaluarea vulnerabilității, impacturile. Schimbările climatice și măsuri de adaptare. Raportul Național al Dezvoltării Umane 2009-2010. UNDP, p.66-78

Effects of sulfur dioxide on vegetation: critical levels, Air Quality Guidelines for Europe. Second Edition. World Health Organization. Regional Office for Europe. WHO Regional Publications, European Series, No. 91, Copenhagen, 2000, p. 226-229

Fuhrer E. Horvath L., Jagodics A., Machon A., Szabados I: Application of new aridity index in Hungarian forestry practice. Idojaras, Quarterly Journal of the Hungarian Meteorological Service. Vol. 115, No. 3, July- September 2011, p. 205-216

Galupa D., Talmaci I: Starea fondului forestier. În: Starea Mediului în Republica Moldova în 2007-2010 (Raport Național). Ch., Nova-Imprim, 2011, p. 106-108

Geiser L.H., Jovan S.E., Glavich D.A., Porter M.K: Lichen-based critical loads for atmospheric nitrogen deposition in Western Oregon and Washington Forests, USA. Environmental Pollution, 158, 2010, p. 2412-2421

Ivan D., Doniţă N: Metode practice pentru studiul ecologic şi geografic al vegetaţiei. Bucureşti, 1975. $250 \mathrm{p}$

Manion P: Decline diseases of complex biotic and abiotic origin. In: vol. Tree disease Concept, 1981, p. 324-339

Mapping critical levels for vegetation, CLRTAP, 2014. Chapter III of Manual on methodologies and criteria for modelling and mapping critical loads and levels and air pollution effects, risks and trends. UNECE Convention on Long-range Transboundary Air Pollution; www.icpmapping.org, accesat 10.11.2016

Moore B., Allard G: Climate change impacts on forest health. Forestry Department Food and Agriculture Organization of the United Nations. Forest Health and Biosecurity Working Papers. Roma, 2008, 45p

Nedealcov M:Resursele agroclimatice în contextul schimbărilor de climă,Tip." Alina Scorohodova" 2012, Chișinău, 306 p.

Nedealcov M., Dediu I., Donica A., Grigoraș N: Utilizarea indicelui de ariditate forestier (FAI) pe teritoriul Republicii Moldova. Conferinţa ştiinţifică cu participare internaţională, "Biodiversitatea în contextul schimbărilor climatice". Academia de Științe a Moldovei. Universitatea Academiei de Științe a Moldovei, Chișinău, 
2016, p.230-233

Nimis P.L., Scheidegger C. and Wolseley P.A. 2002: Monitoring with lichens: monitoring lichens. Kluwer Academic published in association with the NATO Scientific Affairs Division, Dordrecht; London 